УДК 130.2: 37.01

DOI 10.35423/2078-8142.2021.1.1.12

\author{
Д. В. Погрібна, \\ кандидат філософських наук, \\ доиент кафедри іноземних мов
} за професійним спрямуванням та гуманітарних дисциилін Державного університету інфраструктури і технологій, м.Київ, Украӥна e-mail: dariavladyslavivna@gmail.com ORCID: https://orcid.org/0000-0001-6333-8576

\title{
МІСЦЕ ТА ЗНАЧЕННЯ ТВОРУ «СВІТ СОФІЇ» Ю. ГОРДЕРА У ФІЛОСОФІЇ ДЛЯ ДІТЕЙ
}

У статті аналізуеться книга Ю. Гордера «Світ Софії» та визначається ї̈ місие у філософії для дітей як сфери гуманітарного знання. Філософія для дітей у «класичній» моделі представлена як методика Р4С (автор - М. Ліпман). Автор знайомить аудиторію з головними положеннями методики Р4С та порівнює "Світ Софії» з класичними творами М. Ліпмана. Спільними рисами изих творів є: иільова аудиторія (частково), «сократівський діалог», наявність творчої уяви. Проте книга Ю. Гордера вирізняється літературним способом викладу (на відміну від методичних творів М. Ліпмана) та проблематикою ("Світ Софії» аналізує історію розвитку філософських систем; М. Ліпман аналізує філософські проблеми без прив'язки до імен і періодів). «Світ Софії» має такі ознаки Р4С: філософська настанова, «сократівський діалог», інтерактивна взаємодія, саморефлексія. Як підсумок автор надає рекомендаиії щодо особливості викладання твору «Світ Софії» у школі та визначає компетениії, які книга може розвинути в учнів.

Ключові слова: «Світ Софії», Ю. Гордер, філософія для дітей, методика Р4С, М. Ліпман, «сократівський діалог», критичне мислення, саморефлексія.

(C) Погрібна Д. В., 2021 
Філософія для дітей (P4C - Philisophy for children) як сфера гуманітарного знання з'явилася у 1970-х pp. (засновник М. Ліпман) і з кожним роком набуває дедалі більшої актуальності. Адже стає зрозумілим, що це $є$ вірний шлях формування нового освітнього простору та подолання шаблонів стандартизованої та стеоретипізованої освіти. «Любов до мудрості», що «починається 3 подиву» щодо всього існуючого, сприяє формуванню запитів до світу і пошуку відповідей на них, а розвиток рефлексивного мислення та формування критичної настанови $є$ невід'ємною характеристикою сучасного інноваційного фахівця. В епоху домінування багатофункціональної робототехніки світу як ніколи потрібні особистості, що мислять нестандартно, носії актуальних ціннісножиттєвих смислів, здатні до креативних інновацій. Проте формування подібних особистостей запізно починати у дорослому віці, i сучасна парадигма філософського мислення переорієнтовується на дітей та підлітків, зближуючи філософію з педагогікою: «утверджується концепт підлітковості як даність особливого, першочергового соціально-психологічного вікового формату індивідуального людського життя.» $[14$, с. 45]. Якщо рефлексивне мислення почати формувати ще у дитячому віці, навчально-освітній процес перетвориться із соціально-адаптативного на такий, що зумовлюватиме динаміку розвитку критичного мислення, креативності, інноваційності.

У сучасній науці філософія для дітей існує у багатьох варіантах: методичному, описовому, дидактичному, художньонаративному тощо. Вагомим внеском до розвитку філософії для дітей як галузі гуманітарного знання $є$ твір Ю. Гордера «Світ Софії» - виклад філософських систем у вигляді наративу. Популярність цього роману не підлягає сумніву, адже у світі вона для мільйонів «стала настільною книгою» [12, с. 87]. Проте чи є вона філософію для дітей у класичному вигляді чи іiі можна просто вважати допоміжною літературою для вивчення філософії загалом? Щоб дати відповідь на це питання, потрібно здійснити критичний аналіз твору «Світ Софії» та зіставити його з основними положеннями «класичної» філософії для дітей - методикою М. Ліпмана. Визначення валідності книги «Світу Софії» саме як навчально- 
методичного матеріалу в межах філософії для дітей можливо лише шляхом іiі аналізу за відповідними критеріями.

Філософія для дітей $є$ порівняно новою галуззю, проте нараховує вже достатню кількість наукових праць наукового, навчально-методичного, публіцистичного та художнього характеру. Головним першоджерелом, на яке спирається наше дослідження, є книга Ю. Гордера «Світ Софії» [5]. Проте об'єктом нашого аналізу також є методика Р4С, тому ми залучаємо до джерельної бази дотичні даній проблематиці наукові праці. Огляд сучасних концепцій філософії для дітей детально представлений у публікації Н. Адаменко «Світові практики методики викладання філософії: історія та сучасний стан» [1], де не лише викладені основні положення методики М. Ліпмана, а й аналізуються праці найбільш відомих дослідників Р4С, а саме - О. Бреніф'є, Е. М. Шарп, Ф. Осканян, В. Сухомлинський, Дж. Парк та ін. Крім аналізу персоналій у статті Н. Адаменко представлені основні напрями дослідження сучасної філософії для дітей. Також у своєму дослідженні ми спираємося на праці «класиків» Р4С - М. Ліпмана, Е. М. Шарп. Ф. Осканяна $[9 ; 10 ; 11]$ та рецепцію їх творчості українською дослідницею Ю. Кравченко [8]. Що стосується аналізу самого твору «Світ Софії», то вважаємо за доцільне взяти за основу статтю дослідниці В. Смирнової ««Світ Софії» Ю. Гордера: особливості рецепції роману в Росії» [12], де найбільш повно представлені основні дослідження західних та пострадянських мислителів 3 даної проблематики. Аналіз «Світу Софії» в контексті методики Р4С представлений у статті української дослідниці С. Ганаби «Навчати мисленню: епістемологічний проект М. Ліпмана»[4]. Також варто відзначити грунтовний аналіз твору «Світ Софії» у серії філософських програм «Любов до мудрості» Т. Клока [7].

Метою нашої статті є критичний аналіз твору Ю. Гордера «Світ Софії» та визначення його місця у філософії для дітей як сфери гуманітарного знання та засобу всебічного формування особистості. Основними завданнями даного дослідження є:

- презентація книги «Світ Софії» Ю. Гордера як філософського наративу - аналіз змісту та форми, а також методів та прийомів, представлених в даному творі; 
- виклад основних змістовних положень методики Р4С М. Ліпмана та компаративне зіставлення його окремих творів із «Світом Софіï»;

- аналіз книги «Світ Софії» як твору з філософії для дітей;

- визначення значення книги «Світ Софії» для професійного та загального розвитку особистості.

Книга «Світ Софії» була видана Ю. Гордером у 1991 р. - у період, коли світ остаточно став на шлях глобалізаційного розвитку та технізації. За жанром це художній роман з елементами фенте3і, в якому описується знайомство 14-річної дівчинки 3 історією філософських ідей.

I хоча деякі деталі інтер'єру свідчать про атмосферу 30річної давнини, в загальному сенсі твір є зразком сучасної філософської літератури і втілює в собі всі світоглядні тенденції саме XXI ст., а саме - поліваріантну модель розвитку, толерантність, глобалізацію, мультикультуралізм, техніцизм, віртуальну (в творі спроектовану) реальність. В. Смірнова зазначає: «Для роману, у відповідності з традицією постмодерну, властиве множинне кодування: текст може бути прочитаний як роман / виховання / становлення, як авантюрний / детективний роман і як роман філософський» $[12$, с. 81]. Проте у загальному сенсі «Світ Софії» можна вважати історико-філософським дослідженням, адже у творі здійснюється послідовний виклад історико-філософських вчень від давньогрецьких натурфілософів до філософських течій кінця ХХ ст.

Саме класична схема викладу філософських систем із застосуванням методу єдності логічного та історичного дає можливість здійснювати рефлексію над ідеями минулого, зіставляючи їх 3 теперішнім та майбутнім (наприклад, систематизація Аристотелем усіх наукових знань викликала у Софії бажання розкласти все по поличкам у своїй кімнаті і навести «порядок у житті» [5, с. 126]). Не зважаючи на переобтяження іменами, термінами та назвами (що може бути складно для дитячого чи навіть підліткового сприйняття), «історія філософії робить знайомство з історією філософських вчень необхідним підгрунтям не лише вченої підготовки, а й освіти взагалі, оскільки вона вивчає, як виникли ті поняття, на підставі і за допомогою яких ми розмірковуємо як у повсякденно- 
му житті, так і у сфері спеціальних знань про світ нашого досвіду» $[2,17-18]$.

Проте «Світ Софії» - це не просто підручник з історії філософіï, а наратив, який дає можливість 14-річній Софії Амундсен зрозуміти, які питання може поставити людське мислення, наскільки цей світ може бути безмежним, реальність - ілюзорною, а уявлення про стереотипізованість та стабільність - позбавленими сенсу конструктами. За допомогою прийомів самоіронії автор наочно демонструє аудиторії відмінність буденного, «звичайного» дорослим світосприйняття від світу філософії, де завжди має місце подив та осмислення.

Проте історико-філософський виклад матеріалу суперечить «класичній» методиці філософії для дітей, запропонованої в 70х роках минулого століття М. Ліпманом - P4C (Philosophy for children). Згідно із М. Ліпманом та його послідовниками, дітей зовсім не потрібно вчити філософії, адже це викликає переобтяження зайвою інформацією, яка в цьому віці не зможе бути осмислена відповідним чином. Дітей потрібно вчити саме філософуванню, тобто вмінню ставити проблеми, аналізувати, задавати питання, висловлювати свою думку, вести діалог та брати участь у дискусіях. Тому замість методів єдності логічного та історичного та соціокультурного, тут здебільшого застосовується метод проблемнокатегоріального аналізу та моделювання. Тексти та питання до них побудовані таким чином. Головним у філософії для дітей $\epsilon$ побудова конструктивного діалогу за схемою «Питання - відповідь», що призводить до подальшого виникнення рефлексивного мислення. В класичному варіанті М. Ліпмана першим етапом філософії для дітей є «маєвтичний метод Сократа»: «розглядаючи різні можливості кожного партнера спільноти дослідників, за допомогою розумних запитань народжуються власні ідеї та думки» [1, c. 283].

Наступним етапом нашого дослідження буде компаративна характеристика «Світу Софії» Ю. Гордера 3 навчальнометодичними творами М. Ліпмана. Ми обрали найбільш властиві критерії, які зможуть визначити спільність та відмінність твору Ю. Гордера та автора методики Р4С М. Ліпмана. 
Властивою ознакою творів Р4С є те, що вони є логічно взаємопов'язаними та розрахованими на певний вік (наприклад, цільова аудиторія «Відкриття Гарі Столмейера» - 5-6 клас). «Світ Софіï» призначений більше для підлітків - від 14 (в окремих випадках - 12 років), адже там міститься багато фактів та імен, які усвідомити та зрозуміти можна буде лише після засвоєння програмних курсів з історії, літератури, географії, фізики (наприклад, світоглядна течія «романтизм» пояснюється Альберто Ноксом на прикладі відомих німецьких та норвезьких письменників [5, с. 364]). Отже, частково порівнювані твори мають спільну цільову аудиторію.

Щодо способу викладу, то хоча обидва тексти є художніми, книга Ю. Гордера є романом, наративом, де ми спостерігаємо за захоплюючими пригодами дівчинки, іiі дорослішанням, подорожуванням у вигаданій казковій реальності, яка, як часто буває у постмодерні,тісно переплелася з фактичною. Школа М. Ліпмана не дозволяє собі випадкових «казкових прийомів», а навпаки - містить додатковий посібник для вчителів з переліком питань та вправ, а також методичних вказівок: «Спочатку питання послідовно зосереджують дітей на їхніх власних думках, а потім спонукають їх задумуватися над тим, що таке взагалі «мати думки». У зв’язку 3 цим дуже важливо задавати питання саме в тому порядку, в якому вони поставлені» [9, с. 224]. Отже, «Philosophy for children» М. Ліпмана прогнозована на досягнення певних результатів, тоді як визначити, який саме буде вплив «Світу Софії» на підростаюче покоління, практично неможливо.

Роман Ю. Гордера також вирізняється серед творів Р4С проблематикою дослідження. Якщо в першому випадку ми маємо класичну історико-філософську рефлексію, то в другому - аналіз на рівні загальнозначущих проблем. Читач М. Ліпмана може не мати жодного уявлення, що таке філософія і які філософи були в який період, проте створювати уявлення про термінологію, використовувану аналітичним мисленням - «Квантор, суб'єкт, дієслово 3в'язка, предикат» [10, с. 225].

Отже, твір «Світ Софії» не є навчально-методичним твором iз філософії для дітей і розрахований на цільову аудиторію підлітків так званого перехідного віку. Проте роман має всі ознаки твору філософії для дітей, пропонуємо виокремити деякі з них. 
«Сократівський діалог». Знайомство Софії 3 кожним новим розділом філософії починалося 3 того, що вона отримувала коротенькі листки із запитаннями на кшталт: «Хто ти така?» [5, с. 8], «Як можуть земля та вода перетворитися на жабу?» [5, с. 35], «Чи віриш ти у долю?» [5, с. 53] тощо. I лише через деякий час, коли у дівчинки вже визрівали певні відповіді, вона отримувала лекцію 3 того чи іншого філософського періоду, пов'язаного $з$ цими питаннями. Надалі Софія мала можливість зустрічатися зі своїм учителем та ставити запитання вже під час занять, що стимулювало їі до подальших роздумів та досліджень. Адже, «якщо не стимулювати і не підживлювати дитячий потяг до цілісної уяви шляхом систематичного введення дітей до атмосфери філософського діалогу, здатного задовольнити їхню допитливість і прояснити погляди - означає змусити їх прийняти всю сухість вузькоспеціалізованого погляду на знання, який панує в теперішній час у школі, закрити їм шлях до широкого, синоптичного, всеохоплюючого філософського світогляду, до якого вони прагнуть» $[11$, с. 166].

Наступним моментом можна виокремити творчу фантазію. Уроки ніколи не проходили стандартно за партою. Відеозапис зі Стародавніх Афін відкривав для Софії давньогрецьку філософію [5, с. 78], атмосфера готичного собору - Середньовіччя [5, с. 178], яскравий костюм та науково-дослідницька бібліотека - Відродження [5, с. 205]. Для кожної теми був підібраний свій прийом, який стимулював розвиток творчої фантазії учениці та формулювання нею нових нестандартних ідей. Тут ми зустрічаємо і казкових персонажів, і метафоричні вирази, і навіть святкову вечірку у стилі «філософського прийому».

Проте незважаючи на розважливий сюжет та просту художню манеру викладу, «Світ Софії» обгрунтовує філософську настанову, яка докорінно відрізняється від буденної. Лише філософи та діти не розучилися дивуватися, і своїм завдання Альберто Нокс (а насправді - батько дівчинки Хільди, Альберт Мьоллер-Наг, який написав книгу «Світ Софії» для навчання філософському світогляду своєї дочки) вбачав у тому, щоб дівчинка «не потрапила до числа тих, хто приймає дійсність як те, що саме із себе зрозуміле» [5, с. 21]. Для допитливої людини 3 критичним рефлексивним мис- 
ленням дійсність завжди повинна бути проблематичною і породжувати нові питання, адже «розуміння набуває своїх дійсних можливостей лише тоді, коли його попередні думки не є випадковими» [3, с. 319].

Одним з важливих моментів у філософії для дітей є інтерактивна взаємодія - колективне прочитання, групове обговорення, командне проектування, а в окремих випадках - рольові ігри, де «роль розуміється як функціональна форма, що приймається індивідом під час реакції на ситуацію, в якій є присутніми інші індивіди» $[13$, с. 118$]$. Цей момент, хоча й по-різному, обігрується як у творах представників Р4С, так і у книзі Ю. Гордера, який постійно демонструє нові моделі поведінки та результати ефективної взаємодії (наприклад, «філософський прийом», де репліки та дії кожного з учасників остаточно «підштовхнули» Софію до переходу 3 буденної до філософської настанови).

У книзі повною мірою присутній саморефлексивний аналіз. Розкриємо детальніше суть цього поняття. У «Світі Софії» ми бачимо не лише рефлексію учениці над запропонованими їй знаннями, а і їі усвідомлення, що вона є вигаданим персонажем, результатом іронії майора Нага. Проте героїня (Софія, а згодом і Хільда) робить спроби отримати окреме існування, у чому можна простежити паралель 3 нашим буденним сприйняттям, коли людина живе та знаходиться у світі, і в певний момент розуміє, наскільки він може бути лише проектом, де кожен виконує певну соціальну роль. Дослідник Т. Клок проводить паралель з художнім фільмом «Матриця», де всі люди є учасники спроектованої реальності [7]. У даному дослідженні вважаємо за доцільне згадати нетрадиційного філософа Карлоса Кастанеду, який обгрунтовував кончу потребу позбавитися від усвідомлення та аналізу дійсності, що нас оточує, зробити спробу «звільнення» від звичного існування, адже: «Кожен із нас рівною мірою є підданим своїй саморефлексії... Це виявляється у вигляді потреб» [6, с. 624]. I щоб змогти вийти за межі світу, в якому ти знаходишся, потрібно «розбити дзеркало саморефлексії» [6, с. 624] подібно до того, як Альберто Наг і Софія Аммунсен покинули філософський прийом і своє звичне середовище існування, відкривши для себе недоступний для інших світ філоcoфiï. 
Загалом книгу «Світ Софії» можна рекомендувати не лише для прочитання заради особистісного розвитку. Евристичний потенціал роману не викликає сумніву і було б некоректно відносно перспективи розвитку філософії для дітей залишити «Світ Софії» поза увагою. Безперечно, книга може бути введена до шкільної програми в межах курсу літератури, історії чи навіть філософії (якщо така буде передбачена програмою навчального закладу). Проте їі вивчення вимагає, щоб у навчальному процесі були присутні такі моменти:

- діалог між учнями (за принципами «сократівського діалогу»);

- дискусія та колективний пошук рішень («спільнота дослідників»);

- відсутність перфекціонізму вчителя (кожна дитина повинна взяти із твору щось своє, не можна висловлювати оціночних суджень).

Для більш цікавого та ефективного засвоєння можна порекомендувати такі практики: форматі);

- колективне прочитання окремих фрагментів (за «ролями»

- художнє відтворення антуражу (декорації, костюми);

- командна візуалізація (відеоскрайбінг, колективний колаж).

Проте використовуючи згадані або будь-які інші прийоми потрібно пам'ятати, що головним тут завжди є бажання та інтерес учнів.

Книгу «Світ Софії» Ю. Гордера можна вважати не лише популяризаторською, спрощеною версією історії філософії як науки, а й зразковим твором у галузі філософії для дітей. Роман сприяє формуванню рефлексивного мислення та нестандартного погляду на світ, розвитку творчої уяви, комунікативних навичок, вміння взаємодіяти в команді та працювати з великим обсягом інформації. Історико-філософський виклад дає можливість не лише вчитися проблемно-категоріальному аналізу, а й відкрити для себе світ ідей та понять, сформульованих у минулому та сучасності. Це дасть можливість принести до скарбниці філософської мудрості нове, 
відмінне від попереднього знання, здійснити інноваційне дослідження, зробити важливе відкриття. Отже, «Світ Софії» не лише $\epsilon$ актуальним для сучасної філософії для дітей, але й має перспективу навчати філософському мисленню дітей та підлітків протягом багатьох десятиліть.

\section{ЛITEРАТУРА}

1. Адаменко Н. Світові практики методики викладання філософії: історія та сучасний стан. Вісник Інституту розвитку дитини. 2013. Вип. 28. C. $5-11$ $560 \mathrm{c}$.

2. Виндельбанд В.История философии. Киев : Ника-Центр, 1997.

3. Гадамер Х.-Г. Истина и метод. Москва : Прогрес, 1988. 704 с.

4. Ганаба С. «Навчати мисленню»: епістемологічний проект М.Ліпмана. Вісник Інституту розвитку дитини. 2013. Вип. 29. С. 5-11.

5. Гордер Ю. Мир Софи. Санкт-Петербург : Амфора, 2008. 558 с.

6. Кастанеда К. Сила Безмолвия / К. Кастанеда Собрание сочинений: в 3 т. Киев : София, 2001. Т. 3. С. 531-645.

7. Клок Т. Світ Софії. Любов до мудрості. Bun.12 URL: https://www.youtube.com/watch?v=Qu1N7WzqSOo

8. Кравченко Ю. Філософія для дітей: вимога часу. Філософія освіти. 2011. № 1-2(10). С. 288-296.

9. Липман М., Шарп Э. М., Осканян Ф. Открытие Гарри Столтмейера. Юлина Н. Философия для детей. Москва : Ифран, 1996. С. 213216.

10. Липман М., Шарп Э. М., Осканян Ф. Философское исследование. Пособие для учителей. Раздел к главе «Открытие Гарри Столтмейера». Юлина Н. Философия для детей. Москва : Ифран, 1996. С. 213-233.

11. Липман М. Мышление и школьная програма. Юлина Н. Философия для детей. Москва : Ифран, 1996. С. 147-167.

12. Смирнова В. Мир Софии Ю. Гордера: ососбенности рецепции романа в России. Филология и человек. 2017. № 4. С. 80-91.

13. Чепіга В., Кривохвостов В. Використання гри як засобу захисту i збереження психологічного здоровя молодшого школяра у контексті ідей педагогічної філософії. Молодий вчений. 2017. № 9.2(49.2). Вересень. C. 116-120.

14. Цвіркун В. Філосософсько-антропологічний статус підлітковості. Психологія і суспільство. 2013. № 4. С. 45-51. 
15. Философия для детей. Новая философская энциклопедия: в $4 \mathrm{~m}$. URL: http://iph.ras.ru/elib/3209.html

\section{RERERENCES}

Adamenko, N. (2013). World practices of methods of teaching philosophy: history and current state. Bulletin of the Institute of Child Development, 28, 511. [In Ukrainian].

Windelband, V. (1997). The history of philosophy. Kiev: Nika-Center. [In Russian].

Gadamer, H.-G. (1988). Truth and Method. Moscow: Progress. [In Russian].

Hanaba, S. (2013). «Teach thinking»: epistemological project of M. Lipman. Bulletin of the Institute of Child Development, 29, 5-11. [In Ukrainian].

Gaarrder, Y. (2008). Sophie's world. St. Petersburg, SPb: Amphora. [In Russian].

Castaneda, K. (2001). The Power of Silence Vol 1, (pp. 216-233). In Castaneda, K. Collected works (Vols. 1-4). Kiev: Sofia. [In Russian].

Clock, T. (2019). Sophie's world. Retrieved from: https://www.youtube.com/watch?v=Qu1N7WzqSOo [In Ukrainian].

Kravchenko, Y. (2011). Philosophy for children: the requirement of time. Philosophy of education, 21-2, 288-296. [In Ukrainian].

Lipman M., Sharp E. M. \& Oskanian F. (1996). The discovery of Harry Stoltmeyer In N.Yulina. Philosophy for children (pp. 213-216). Moscow: Ifran. [In Russian].

Lipman, M., Sharp, E. M. \& Oskanyan, F. (1996). Philosophical research. A guide for teachers. Section to the chapter «The Discovery of Harry Stoltmeyer». In N. Yulina. Philosophy for children (pp. 216-233).Moscow: Ifran. [In Russian].

Lipman, M. (1996). Thinking and school program. In N. Yulina. Philosophy for children (pp.147-167). Moscow: Ifran. [In Russian].

Smirnova, V. (2017). «Sophie's world» of Y. Gaarder: features of the reception of the novel in Russia. Philology and human, 4, 80-91. [In Russian].

Chepiga, V., Krivokhvostov, V. (2017). The use of games as a means of protecting and preserving the psychological health of primary school children in 
the context of the ideas of pedagogical philosophy. Young scientist, 49.2, 116120. [In Ukrainian].

Tsvirkun, V. (2013). Philosophical and anthropological status of adolescence. Psychology and society, 4, 45-51. [In Ukrainian].

Philosophy for children. In New Philosophical Encyclopedia. Retrieved from http://iph.ras.ru/elib/3209.html [In Russian].

\section{Daria Pohribna}

Candidate of Philosophical Sciences (Ph D.), Associate Professorof the Department of Foreign Languages for Specific Purpose and Humanitarian Subjects, State University of Infrastructure and Technologies; Kyiv, Ukraine; email: dariavladyslavivna@-gmail.com; ORCID: https://orcid.org/0000-00016333-8576

\section{J. Gaarder's «Sophie's world»: philosophy for children as a narrative}

\section{Abstracts}

The article analyzes J. Gaarder's s book «Sophie's world» and defines its place in philosophy for children as a shpere of humanities. Philosophy for children in the "classical» model is presented as a method of P4C (author M. Lipman). The author presents the audience the main thesises and methods of the P4C method and compares «Sophie's world» with classic works of M. Lipman. The same moments of these works are: the target audience (partly), «socratic dialogue», the presence of creative imagination. However, the book by Y. Gaarder differs in the literary form of presentation (unlike the methodical works of M. Lipman) and issues («Sophie's world» analyzes the history of philosophical systems; M. Lipman analyzes philosophical problems without reference to names and periods). «Sophie's world» has the following features of P4C: philosophical guidance, "socratic dialogue», critical thinking, the formation of responses to questions, interactive interaction, self-reflection. As a result, the author provides recommendations to teachers on the peculiarities of teaching the work «World of Sophia» at school and identifies the competencies that the book can develop in students. «Sophie's world» can be introduced into the school programm. However, teachers need to follow special recommendations. Children must express their opinions themselves and be a "Community of researchers». Everyone can to tell their own opinion. To interest students, the teacher can offer: video scribing, team collage, artistic repro- 
duction of the atmosphere (for e[ample decoration), role play. «Sophie's world» is a relevant work for philosophy for children. Y. Gaarder's book can form the reflective thinking and non-standard view of the world. The novel also develops communication skills, the ability to work in a team and ability to work with a large amount of information. «Sophie's world» is very important and actual book for modern philosophy for children

Keywords: «Sophie's world», Y. Gaarder, philosophy for children, M. Lipman, methodology P4C, «socratic dialogue», critical thinking, self-reflection. 